\title{
Peningkatan Hasil Belajar PAI Melalui Penerapan Metode Index Card Match Dengan Materi Makna Hari Akhir Pada Siswa Kelas VI SD Negeri 21 Banda Aceh Tahun Pelajaran 2019/2020
}

\author{
Muttaqiah \\ Guru SD Negeri 21 Banda Aceh
}

\begin{abstract}
Abstrak
Penelitian Tindakan Kelas ini berjudul "Peningkatan Hasil Belajar PAI Melalui Penerapan Metode Index Card Match Dengan Materi Makna Hari Akhir Pada Siswa Kelas VI SD Negeri 21 Banda Aceh Tahun Pelajaran 2019/2020". Tujuan penelitian ini adalah untuk meningkatkan hasil belajar siswa dengan metode Index Card Match dalam pembelajaran PAI materi makna hari akhir di kelas VI SD Negeri 21 Banda Aceh. Penelitian dilaksanakan di SD Negeri 21 Banda Aceh selama 3 bulan mulai Januari sampai dengan Maret 2020 pada siswa kelas VI yang berjumlah 28 orang. Alat pengumpulan data dalam penelitian ini adalah menggunakan media lembar kerja siswa dan tes untuk data hasil belajar siswa. Teknik pengumpulan data dengan menggunakan metode observasi dan tes. Analisis data menggunakan hasil observasi yang dilakukan dengan menghitung persentase skor rata-rata untuk setiap indikator dan data hasil belajar siswa dilakukan dengan menghitung persentase keberhasilan siswa. Hasil analisis diperoleh bahwa untuk setiap siklusnya rata-rata pada siklus I adalah $75 \%$, rata-rata dan pada siklus II adalah $91,4 \%$ dan rata-rata kenaikan nilai adalah; rata-rata hasil belajar siswa pada siklus I yaitu 70\%, siklus II 82,50\%. Dari hasil yang diperoleh maka disimpulkan bahwa penerapan metode Index Card Match dapat meningkatkan hasil belajar siswa dalam pembelajaran PAI materi makna hari akhir di kelas VI SD Negeri 21 Banda Aceh sangat memuaskan.
\end{abstract}

Kata Kunci : Prestasi belajar, Penerapan, Metode, Index Card Match.

\section{PENDAHULUAN}

Pendidikan merupakan belajar dari pengalaman dapat didefinisikan sebagai perubahan yang relatif tetap yang terjadi pada segala macam keseluruhan tingkah laku suatu proses organisme sebagai hasil pengalaman. Belajar mengakibatkan berbagai unsur yang ada, berupa kondisi fisik dan psikis orang yang belajar. Kedua kondisi tersebut sangat intern dan berpengaruh terhadap keberhasilan belajar. Oleh karena itu, belajar dapat terjadi kapan dan dimana saja.

Perolehan hasil belajar yang maksimal perlu adanya dukungan dari guru sebagai pengajar serta semua arahan yang disampaikan oleh guru. Salah satu stimulus yang dapat diciptakan oleh seorang guru dalam meningkatkan hasil dalam pembelajaran adalah dengan menerapkan metode pembelajaran. Penggunaan media oleh guru akan menentukan bagaimana siswa akan merasa nyaman pada saat pembelajaran berlangsung dan juga menarik tidaknya minat belajar siswa.

Saat ini pelaksanaan kegiatan pembelajaran di SD kelas VI untuk setiap mata pelajaran dilakukan "secara murni" mata pelajaran yaitu hanya mempelajari standar kompetensi dasar yang berhubungan dengan mata pelajaran tersebut. Pada 
pembelajaran yang memisahkan penyajian muda pelajaran secara tegas kurang mengembangkan anak untuk berpikir holistik dan membuat kesulitan bagi peserta didik. Dengan pelaksanaan kegiatan, seperti yang disebutkan, muncul permasalahan pada yaitu tingginya angka mengulang kelas dan putus sekolah.

Hasil belajar siswa menunjukkan angka dimana masih sering di bawah Kriteria Ketuntasan Minimum (KKM) yang telah ditetapkan diSD Negeri 21 Banda Aceh yaitu 75. Sebagai pengantisipasi di atas, dan untuk menumbuhkan interaksi guru dengan siswa secara efektif perlu diupayakan dengan menggunkan metode pembelajaran yang tepat. Karena dengan penerapan metode yang tepat nantinya akan membantu keberhasilan pembelajaran di kelas. Oleh karena itu, penerapan metode pembelajaran harus sesuai dengan materi yang disampaikan pada saat itu karena tidak ada suatu metode yang paling baik untuk semua materi.

Berdasarkan latar belakang masalah yang ada di atas, maka peneliti tertarik melakukan penelitian dengan dengan judul "Peningkatan prestasi belajar PAI melalui penerapan Metode Index Card Match dengan Materi Hari Akhir pada Siswa Kelas VI SD Negeri 21 Banda Aceh tahun pelajaran 2019/2020”.

\section{Tujuan penelitian}

Untuk mengetahui peningkatan hasil belajar siswa dengan metode Index Card Match dalam pembelajaran PAI materi Hari Akhir di kelas VI SD Negeri 21 Banda Aceh tahun pelajaran 2019/2020”.

\section{KAJIAN PUSTAKA}

\section{Hasil Belajar}

Hasil belajar adalah kemampuan-kemampuan yang dimiliki peserta didik setelah ia menerima pengalaman belajarnya. Howard Kingsley membagi tiga macam hasil belajar, yakni a) Keterampilan dan kebiasaan, b) Pengetahuan dan pengertian, c) Sikap dan cita-cita. Masing-masing jenis hasil belajar dapat diisi dengan bahan yang telah ditetapkan dalam kurikulum. Adapun Gagne membagi lima kategori hasil belajar, yakni a) Informasi verbal, b) Keterampilan intelektual, c) Strategi kognitif, d) Sikap, dan e) Keterampilan motoris. Dalam sistem pendidikan nasional rumusan tujuan pendidikan, baik tujuan kurikuler, tujuan institusional maupun tujuan instruksional, menggunakan klasifikasi hasil belajar dari Benyamin S. Bloom yang secara garis besar membaginya menjadi tiga ranah, ranah kognitif, ranah afektif dan Menurut Wasty Soemanto (1990), hasil belajar akan dipengaruhi oleh banyak faktor.

\section{Penerapan Metode Index Card Match}

Metode Index Card Match merupakan salah satu dari metode pembelajaran berbasis PAIKEM. Maka sebelum membahas tentang penerapan metode Index Card Match, perlu kita pahami dulu tentang pengertian PAIKEM. Pengertian PAIKEM secara bahasa dan istilah dapat dijelaskan secara singkat, ia merupakan singkatan dari pembelajaran aktif, inovatif, kreatif, efektif, dan menyenangkan. Istilah aktif, maksudnya pembelajaran adalah sebuah proses aktif membangun makna dan pemahaman dari informasi, ilmu pengetahuan maupun pengalaman oleh peserta didik sendiri. Istilah inovatif, dimaksudkan dalam proses pembelajaran diharapkan muncul inovasi-inovasi positif yang lebih baik. Istilah kreatif memiliki makna bahwa 
pembelajaran merupakan sebuah proses mengembang kan kreatifitas peserta didik, karena pada dasarnya setiap individu memiliki imajinasi dan rasa ingin tau yang tidak pernah berhenti dalam suasana yang menyenangkan dan mengesankan.

Index Card Match merupakan salah satu dari model atau strategi pembelajaran aktif (active learning) berbasis PAIKEM sebagai alternatif yang dapat digunakan oleh guru untuk dapat menambah keaktifan peserta didik, baik secara individu maupun kelompok. Dalam bukunya Melvin L. Silberman (1997), Index Card Match dari bahasa Inggris yang artinya mencari jodoh kartu tanya jawab. Langkah-langkah penerapan metode Index Card Match:

1) Guru membuka pelajaran kelas dan menyampaikan bahan materi pokok.

2) Guru menyiapkan potongan-potongan kertas sejumlah peserta dalam kelas dan kertas tersebut dibagi menjadi dua kelompok.

3) Kertas yang disiapkan tersebut telah diisi dengan pertanyaan-pertanyaan tentang materi yang telah diberikan sebelumnya.

4) Pada potongan kertas yang lain, telah dituliskan jawaban dari pertanyaan-pertanyaan yang telah dibuat.

5) Kertas tersebut dikocok sehingga akan tercampur antara soal dan jawaban

6) Guru membagi setiap siswa satu kertas. Dengan menjelaskan bahwa ini adalah aktifitas yang dilakukan berpasangan. Sebagian peserta akan mendapatkan soal, dan sebagian yang lain akan mendapatkan jawaban.

7) Siswa diberikan waktu untuk memikirkan jawaban dari pertanyaan yang diterima nya, dan sebaliknya.

8) Selanjutnya dilakukan pembahasan, dengan cara guru meminta siswa untuk mencari pasangannya, dimulai dengan mempersilakan kepada siswa yang membawa kertas berisi pertanyaan untuk membaca dengan suara keras, dan siswa yang membawa kertas berisi jawaban mendengarkan sekaligus menjawab dengan keras (bagi yang merasa jawabannya sesuai/tepat). Dan dijelaskan juga agar mereka tidak memberikan materi yang mereka dapatkan kepada teman yang lain.

9) Guru mengakhiri proses pembelajaran ini dengan apresiasi, klarifikasi, kesimpulan dan evaluasi serta tindak lanjut.

\section{Pembelajaran PAI di Sekolah Dasar}

Pendidikan Agama Islam adalah upaya sadar dan terencana dalam menyiapkan peserta didik untuk mengenal, memahami, menghayati, hingga mengimani ajaran agama Islam. Sedangkan pengertian Pendidikan Agama Islam menurut Zakiah Daradjat, dkk (1996) adalah pendidikan dengan melalui anjuran-anjuran agama Islam, yaitu berupa bimbingan dan asuhan terhadap anak didik agar nantinya setelah selesai dari pendidikan ia dapat memahami, menghayati dan menjadikan ajaran-ajaran agama Islam yang telah diyakininya secara menyeluruh, serta menjadikan ajaran agama Islam itu sebagai suatu pandangan hidupnya demi keselamatan dan kesejahteraan hidup di dunia maupun di akhirat kelak.

\section{Ruang lingkup PAI}

Ruang lingkup materi Pendidikan Agama Islam (kurikulum 2013) pada dasarnya mencakup tujuh unsur pokok yaitu Al-quran, hadist, keimanan, syari'ah, ibadah muamalah, akhlak, dan tarikh (sejarah Islam) Ruang lingkup Pendidikan Agama Islam 
meliputi aspek-aspek sebagai berikut: Al-Quran dan Hadits, Aqidah, Akhlak, Fiqih, Tarikh dan Kebudayaan Islam. Pendidikan Agama Islam menekankan keseimbangan, keselarasan, dan keserasian antara hubungan manusia dengan Allah SWT, hubungan manusia dengan sesama manusia, hubungan manusia dengan diri sendiri dan hubungan manusia dengan alam sekitarnya.

\section{METODELOGI PENELITIAN}

\section{Pendekatan dan Jenis Penelitian}

Pendekatan yang digunakan dalam penelitian ini adalah pendekatan kualitatif yaitu untuk mengkaji keadaan alamiah siswa mengikuti pembelajaran penerapan metode index card match.

\section{Tempat dan Waktu Penelitian}

Penelitian tindakan kelas ini diadakan di kelas VI SD Negeri 21 Banda Aceh selama lebih kurang 3 bulan, dimulai dari bulan Januari dan berakhir Maret 2020 tahun pelajaran 2019/2020".

\section{Subjek Penelitian}

Subjek penelitian yang digunakan dalam penelitian ini adalah siswa kelas VI SD Negeri 21 Banda Aceh yang berjumlah 28 orang yang terdiri dari siswa laki-laki dan perempuan.

\section{Teknik Pengumpulan Data}

Tehnik analisis data menggunakan tes, observasi, dokumentasi, wawancara.

\section{Prosedur Penelitian}

Penelitian ini dilaksanakan dalam 2 siklus. Tiap siklus terdiri atas satu kali pertemuan. Masing-masing siklus terdiri atas empat tahap, yaitu (1) perencanaan, (2) tindakan, (3) observasi, (4) refleksi. Keempat tahapan ini digunakan secara sistematis dan diterapkan dalam dua siklus yaitu siklus I dan siklus II.

\section{Teknik Analisis Data}

Analisis kuantitatif juga digunakan untuk menghitung data nontes berupa angket dan observasi. Observasi aktivitas siswa dilakukan oleh pengamat selama pelaksanaan tindakan, dengan berpedoman pada lembar observasi yang disediakan peneliti. Untuk memperoleh presentase kreativitas, kemampuan, dan hasil belajar siswa, teknik analisis data yang digunakan adalah statistik deskriptif di atas diolah dengan rumus persentase sederhana yang dikemukan oleh Sudjana (2002:239) yaitu:

$$
P=\frac{F}{N} \times 100 \%,
$$

$$
\begin{array}{llll}
\text { Keterangan: } & \mathrm{P} & = & \text { angka persentase } \\
\mathrm{F} & = & \text { frekuensi jawaban } \\
\mathrm{N} & = & \text { jumlah siswa } \\
100 \% & = & \text { bilangan konstan (tetap) }
\end{array}
$$




\section{HASIL PENELITIAN DAN PEMBAHASAN Deskripsi Kondisi Awal}

Setelah dilakukan wawancara kepada guru wali kelas, maka diperoleh hasil bahwa jumlah siswa kelas VI keseluruhan berjumlah 28 orang.Hasil wawancara dengan siswa juga menunjukkan bahwa siswa kurang mendapatkan motivasi dalam belajar Pendidikan Agama Islam (PAI) baik di sekolah maupun di rumah.

Kedua siswa tersebut beranggapan bahwa mereka kurang mendapatkan perhatian tentang Pendidikan Agama Islam sehingga belajar PAI dirasa kesusahannya. Terutama kekurangan yang mereka rasakan dalam hal pendalaman materi seputar Hari Akhir. Melihat banyak penyampaian siswa tentang kurangnya motivasi baik dari diri sendiri maupun lingkungan, membuat peneliti menggunakan metode pembelajaran yang membuat siswa ikut serta berpartisipasi aktif dalam pembelajaran Pendidikan Agama Islam (PAI) di kelas.

Hasil belajar siswa menunjukkan angka dimana masih jauh di bawah Kriteria ketuntasan Minimum (KKM) yang telah ditetapkan di SD Negeri 21 Banda Aceh yaitu 70. Sebagai pengantisipasi di atas dan untuk menumbuhkan interaksi guru dengan siswa secara efektif perlu diupayakan dengan menggunakan metode pembelajaran yang tepat.

\section{Hasil penelitian \\ Siklus I}

a. Perencanaan

Perencanaan merupakan tahapan awal yang harus dilakukan peneliti sebelum melakukan tindakan. Di dalam tahapan perencanaan ini tercermin pandangan ke depan, serta fleksibel untuk menerima efek yang tak terduga dan dengan rencana tersebut secara dini kita dapat mengatasi masalah. Perencanaan yang baik akan lebih mudah untuk mengatasi kesulitan dan mendorong untuk bertindak dengan lebih efektif. Pada tahap ini, peneliti mempersiapkan rencana pengajaran yang mengacu pada tujuan pembelajaran. Di samping rencana pembelajaran, perlu dipersiapkan juga alat-alat yang menunjang pembelajaran seperti papan tulis, LCD, buku pelajaran dan lain sebagainya. Peneliti juga perlu melakukan wawancara kepada siswa kelas VI SD Negeri 21 Banda Aceh untuk mengetahui keadaan siswa sebelum melakukan tindakan.

b. Tindakan

Tindakan merupakan penerapan dari perencanaan yang telah dibuat yaitu dalam penelitian ini penggunaan media pembelajaran yang bertujuan untuk inovasi. Pada tahap ini merupakan pelaksanaan dari perencanaan yang telah dipersiapkan peneliti. Proses tindakan dalam penelitian ini meliputi kegiatan awal, kegiatan inti dan kegiatan akhir pada saat proses pembelajaran berlangsung.juga mengemukakan manfaat dan tujuan pembelajaran agar siswa tertarik dengan materi yang akan diajarkan dan memiliki motivasi dalam pembelajaran PAI.

Kegiatan selanjutnya peneliti menyampaikan materi Hari Akhir yaitu. yang disajikan melalui media slide power point. Slide yang ditampilkan berupa materi yang berkaitan serta poin-poin penting yang berhubungan dengan Hari Akhir.

Kemudian dilanjutkan dengan memasangkan kartu atau metode yang digunakan peneliti yakni Index Card Match dimana dalam permainan ini memanfaatkan kartukartu yang berbentuk bintang dan persegi panjang yang ditempatkan di atas meja agar 
siswa dapat menemukan pasangan dari kartu yang dipegangnya, tujuan permainan ini agar lebih bermakna dan menarik siswa belajar PAI pada materi tersebut.

Pada kegiatan akhir, peneliti memberikan tes kepada siswa melalui gambar buta atau diagram kosong, kemudian peneliti bersama siswa melakukan refleksi terhadap pembelajaran yang telah berlangsung dan siswa diminta mempelajari kembali materi yang telah diajarkan. Peneliti juga memberikan kesempatan bagi siswa yang ingin bertanya. Kemudian melaksanakan post test dan terakhir peneliti memberikan motivasi kepada seluruh siswa agar tetap bersemangat belajar dan berlatih materi yang telah disampaikan.

Pada akhir pertemuan atau pada pertemuan berikutnya, peneliti melakukan wawancara kepada beberapa siswa agar diperoleh data non tes pada siklus I.

c. Observasi/ Pengamatan

Pengamatan ini berfungsi untuk melihat dan mendokumentasikan pengaruhpengaruh yang diakibatkan oleh tindakan dalam kelas. Hasil pengamatan ini merupakan dasar dilakukannya refleksi sehingga pengamatan yang dilakukan harus dapat menceritakan keadaan yang sesungguhnya. Dalam pengamatan, hal-hal yang perlu dicatat oleh peneliti adalah proses dari tindakan, efek-efek tindakan, lingkungan dan hambatan-hambatan yang muncul. Untuk melakukan pengamatan dipersiapkan lembar pengamatan yang telah disusun. Lembar pengamatan mencakup beberapa aspek aktifitas siswa. Hasil pengamatan yang diperoleh dianalisis.

Ada tujuh aspek yang diamati oleh observer, antara lain: a) kesiapan siswa, b) antusiasme siswa, c) perhatian siswa terhadap arahan dan instruksi guru, d) semangat siswa dalam mengikuti pelajaran, e) keaktifan siswa dan f) kemudahan siswa dalam mengikuti permainan dan g) keberanian siswa dalam menyampaikan materi yang telah dipelajari.

d. Refleksi

Refleksi dilakukan peneliti bersama guru dan observer yang meliputi kegiatan: analisis, sintesis, penafsiran (penginterpretasian), menjelaskan dan menyimpulkan. Hasil dari refleksi adalah diadakannya revisi terhadap perencanaan yang telah dilaksanakan,memperbaiki kinerja peneliti pada pertemuan selanjutnya dan memperbaiki penggunaan media pembelajaran. Dengan demikian PTK tidak dapat dilaksanakan dalam sekali pertemuan karena hasil refleksi membutuhkan waktu untuk melakukannya sebagai planning untuk siklus selanjutnya.

Siklus I bertujuan untuk mengetahui tingkat pemahaman yang kemudian mampu mengungkapkan secara lisan terkait daur air, yang kemudian digunakan sebagai bahan refleksi untuk melakukan tindakan pada siklus II. Sedangkan siklus II dilakukan untuk memperbaiki pelaksanaan pembelajaran yang didasarkan pada refleksi siklus I.

\section{Siklus II}

Berdasarkan refleksi pada siklus I, telah dilakukan kegiatan-kegiatan perbaikan rencana dan tindakan pada siklus II. Sama halnya dengan prosedur penelitian pada siklus I,pada siklus II ini juga terdiri atas empat tahapan, yaitu : perencanaan, tindakan, observasi dan refleksi. Adapun langkah-langkah yang dilakukan pada siklus II sebagai berikut.

a. Perencanaan 
Perencanaan yang dilakukan pada siklus II merupakan perbaikan dari perencanaan siklus I. Berdasarkan uraian refleksi siklus I di atas, perencanaan pada siklus II ini merupakan upaya memperbaiki kekurangan-kekurangan yang ditemukan setelah dilakukan refleksi siklus I. Perbaikan-perbaikan yang dilakukan sebagai bentuk perencanaan pada siklus II ini meliputi:

a. Memperbaiki skenario pembelajaran PAI di kelas

b. Mempersiapkan permainan dengan bentuk kartu yang lebih menarik untuk siswa.

c. Memperbaiki pengawasan dan pengamatan yang lebih agar siswa lebih tertib dan teratur

d. Memotivasi siswa agar lebih bersemangat dalam mengikuti kegiatan pembelajaran PAI menggunakan permainan kartu.

\section{b. Tindakan}

Pada tahap ini merupakan pelaksanaan dari perencanaan yang telah dipersiapkan peneliti. Proses tindakan dalam penelitian ini meliputi kegiatan awal, kegiatan inti dan kegiatan akhir pada saat proses pembelajaran berlangsung.

Sebelum melakukan tindakan, peneliti mengkondisikan kelas. Hal ini untuk mempermudah peneliti dalam penilaian PAI. Dalam kegiatan awal, peneliti mengkondisikan siswa agar siap melaksanakan proses pembelajaran. Kegiatan awal ini berupa kegiatan peneliti menyapa siswa Hal ini menunjukkan bahwa peneliti mensintesis siswa untuk aktif dan respon terhadap pembelajaran PAI.

Berdasarkan hasil wawancara dan dokumentasi yang telah diperoleh dari siswa kelas VI, proses pembelajaran sebelum pelaksanaan penelitian ini masih menggunakan metode ceramah. Guru mengawali dengan menjelaskan materi Hari Akhir dengan membacakan apa yang ada di buku. Saat guru menjelaskan siswa diminta untuk mendengarkan dan jika ada hal-hal yang dirasa tidak mengerti, siswa dapat langsung bertanya pada guru. Setelah guru selesai menjelaskan materi. Untuk pelaksanaan pembelajaran selanjutnya guru meminta siswa mengerjakan soal-soal lembar kerja siswa yang ada di dalam bahan ajar. Dari soal tersebut dikerjakan oleh siswa dan dikoreksi secara bersama oleh guru dan siswa untuk mengetahui jawaban yang tepat.

Berdasarkan wawancara dengan guru menggunakan panduan angket keaktifan dapat ditentukan rata-rata persentasinya adalah seperti yang terlihat pada tabel berikut:

Tabel Rata-Rata Persentasi Penilaian Keaktifan Siswa Pra Siklus

\begin{tabular}{|c|l|c|}
\hline No & \multicolumn{1}{|c|}{ Aspek yang Diamati } & Rata-rata \\
\hline 1. & Kesiapan siswa dalam menerima pembelajaran PAI & 20 \\
\hline 2. & Antusiasme siswa dalam mengikuti proses pembelajaran PAI & 40 \\
\hline 3. & $\begin{array}{l}\text { Perhatian siswa terhadap arahan guru selama pembelajaran PAI } \\
\text { berlangsung }\end{array}$ & 30 \\
\hline 4. & Semangat siswa dalam mengikuti pembelajaran PAI & 30 \\
\hline 5. & Keaktifan siswa dalam pembelajaran PAI saat berlangsung & 30 \\
\hline 6. & $\begin{array}{l}\text { Kemudahan siswa dalam menerima materi Hari Akhir yang telah } \\
\text { disampaikan }\end{array}$ & 40 \\
\hline 7. & Keberanian siswa dalam menyampaikan materi yang telah dipelajari & 30 \\
\hline \multicolumn{2}{|l|}{ Rata-rata keaktifan } & 31,4 \\
\hline
\end{tabular}

Dari hasil pengamatan keaktifan siswa dalam proses pembelajaran pra siklus dapat disimpulkan bahwa siswa belum terlihat aktif dalam proses pembelajaran. Siswa 
masih banyak mendengarkan dalam memahami konsep materi yang disampaikan. Sehingga dalam proses pembelajaran masih bergantung pada guru. Hal ini juga ditunjukkan dari rata-rata persentasi keaktifan siswa kelas VI menunjukkan angka $31,4 \%$ yang masih berada jauh di bawah indikator keaktifan yang ditentukan yaitu $70 \%$. Melalui pengamatan ketika pelaksanaan pembelajaran siklus I dengan menggunakan angket keaktifan didapat nilai (terlampir) yang rata-ratanya dapat dilihat pada tabel berikut ini:

Tabel Rata-Rata Persentasi Penilaian Keaktifan Siswa Siklus I

\begin{tabular}{|c|l|c|}
\hline No & \multicolumn{1}{|c|}{ Aspek yang Diamati } & Rata-rata \\
\hline 1. & Kesiapan siswa dalam menerima pembelajaran Tematik & 60 \\
\hline 2. & Antusiasme siswa dalam mengikuti proses pembelajaran Tematik & 40 \\
\hline 3. & $\begin{array}{l}\text { Perhatian siswa terhadap arahan guru selama pembelajaran Tematik } \\
\text { berlangsung }\end{array}$ & 70 \\
\hline 4. & Semangat siswa dalam mengikuti pembelajaran Tematik & 60 \\
\hline 5. & Keaktifan siswa dalam pembelajaran Tematik saat berlangsung & 60 \\
\hline 6. & Kemudahan siswa dalam menerima materi daur air yang disampaikan & 60 \\
\hline 7. & Keberanian siswa dalam menyampaikan materi yang telah dipelajari & 70 \\
\hline \multicolumn{2}{|l|}{ Rata-rata keaktifan } & 60 \\
\hline
\end{tabular}

Berdasarkan nilai keaktifan siswa dalam pembelajaran dapat disimpulkan bahwa siswa sudah mulai terlihat aktif dalam proses pembelajaran walaupun belum optimal sesuai dengan harapan. Siswa sudah banyak yang terlihat aktif bertanya, menjawab pertanyaan, menulis, menyelesaikan masalah secara mandiri. Sehingga dalam proses pembelajaran siswa sudah tidak lagi bergantung pada guru. Hal ini juga ditunjukkan dari rata-rata persentase hasil penilaian keaktifan siswa yaitu $60 \%$. Walaupun belum mencapai indikator keaktifan siswa dalam pembelajaran, tapi jika dibandingkan dengan pembelajaran sebelumnya yakni pada pra siklus, rata-rata siswa sudah mengalami perubahan yang signifikan.

Berdasarkan hasil pengamatan keaktifan siswa dalam proses pembelajaran siklus II dapat dikatakan bahwa semua siswa sudah terlibat aktif dalam proses pembelajaran. Siswa secara individu hampir keseluruhan terlihat aktif bertanya, menjawab pertanyaan, menulis, menyelesaikan tugas. Sehingga dalam proses pembelajaran siswa sudah tidak lagi bergantung pada guru. hal ini juga ditunjukkan dari prosentasi keaktifan pada tiap anak (terlampir). Rata-rata prosentasi keaktifan pembelajaran siklus II dapat dilihat pada tabel berikut ini:

Tabel Rata-rata persentasi penilaian keaktifan siswa siklus II

\begin{tabular}{|c|l|c|}
\hline No & \multicolumn{1}{|c|}{ Aspek yang Diamati } & Rata-rata \\
\hline 1. & Kesiapan siswa dalam menerima pembelajaran Tematik & 100 \\
\hline 2. & Antusiasme siswa dalam mengikuti proses pembelajaran Tematik & 70 \\
\hline 3. & $\begin{array}{l}\text { Perhatian siswa terhadap arahan guru selama pembelajaran Tematik } \\
\text { berlangsung }\end{array}$ & 100 \\
\hline 4. & Semangat siswa dalam mengikuti pembelajaran Tematik & 100 \\
\hline 5. & Keaktifan siswa dalam pembelajaran Tematik saat berlangsung & 100 \\
\hline 6. & Kemudahan siswa dalam menerima materi daur air yang disampaikan & 70 \\
\hline 7. & Keberanian siswa dalam menyampaikan materi yang telah dipelajari & 100 \\
\hline \multicolumn{2}{l}{ Rata-rata keaktifan } & 91,4 \\
\hline
\end{tabular}


Keaktifan siswa pada siklus II ini semuanya sudah di atas indikator yang ditentukan. Hal itu dapat dilihat dari tabel di atas menunjukkan di atas $70 \%$. Jika dibandingkan dengan pra siklus dan siklus I, keaktifan siswa di siklus II ini sudah menunjukkan adanya peningkatan yang signifikan yaitu sebesar 91,4\%. Kenaikan nilai rata-rata subjek penelitian dalam bentuk grafik sebagai berikut:

\section{Grafik Kenaikan Penilaian Keaktifan Siswa setiap Siklus}

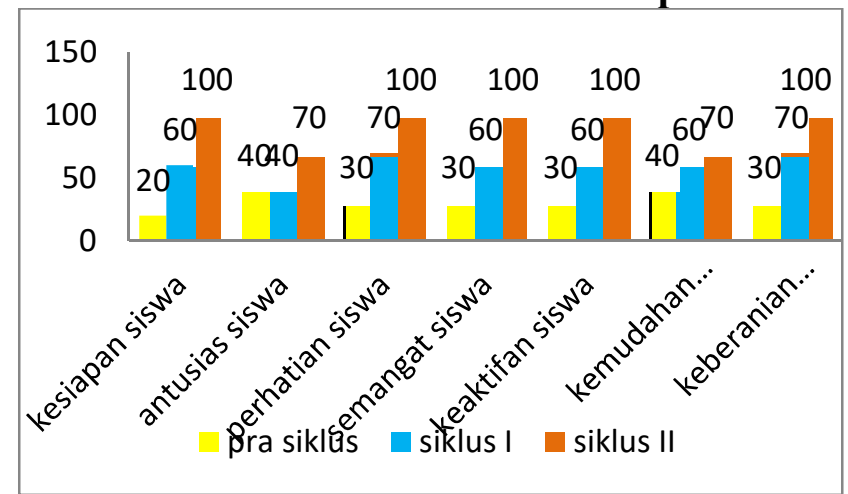

Skor observasi penilaian keaktifan siswa pada setiap siklus menunjukkan peningkatan skor pada setiap aspeknya. Hal ini menunjukkan perubahan tingkah laku siswa ke arah yang lebih baik selama proses pembelajaran pada setiap pertemuan berlangsung.

\section{Pembahasan}

\section{a. Pra Siklus}

Dari hasil nilai yang diperoleh pada pretest kelas VI dapat disimpulkan bahwa anak belum menguasai konsep materi tersebut. Hal ini dapat dilihat dari nilai rata-rata kelas pada materi Hari Akhir pada pretest adalah 45,00 yang masih berada jauh di bawah KKM yang ditentukan sekolah yaitu 70 .

1) Ketuntasan Klasikal

Dari ketuntasan klasikal di atas dapat disimpulkan bahwa ketuntasan klasikal pembelajaran Tematik dengan materi Hari Akhir pada pretest adalah 0\% sehingga masih jauh di bawah indikator yang ditentukan yaitu 75\%.

Pelaksanaan pembelajaran siklus I dilaksanakan pada tanggal 8 dan 15 Agustus 2018. Berikut hasil pembelajaran siklus I yang dilihat dari pemahaman konsep dan ketuntasan klasikal:

\section{1) Pemahaman Konsep}

Dari hasil penilaian pelaksanan pembelajaran siklus I menerapkan Metode Index Card Match yang rata-ratanya dapat dilihat pada tabel berikut:

Berdasarkan rata-rata nilai di atas dapat disimpulkan bahwa siswa sudah mulai memahami materi Hari Akhir.Hal ini ditandai dengan siswa sudah bisa menyebutkan contoh Hari Akhir yang telah dipelajari, melalui potongan kertas, serta mencocokkan antara contoh kehidupan sehari-hari. Pemahaman konsep Hari Akhir juga dapat ditunjukkan dari rata-rata nilai siklus I sebesar 62,50. Nilai rata-rata pada siklus I belum menunjukkan di atas indikator yang ditetapkan yaitu 70. Jika dibandingkan dengan nilai rata-rata pemahaman konsep pra siklus sebelumnya, nilai siswa sudah mengalami kenaikan yang signifikan. Akan tetapi, perlu diadakan pertemuan kembali melalui siklus II dengan pembaruan kertas, slide yang ditampilkan. 


\section{2) Ketuntasan Klasikal}

Persentase ketuntasan belajar pada siklus I sebesar 25\% dan jika diukur dengan indikator ketuntasan klasikal yang ditentukan yaitu $75 \%$, bisa dikatakan belum memenuhi dan masih berada di bawah standar KKM. Tetapi jika dibandingkan dengan ketuntasan klasikal pada pra siklus sudah mengalami kenaikan yang signifikan. Pada siklus I pertemuan 1 semua siswa belum tuntas KKM. Sedangkan pada siklus I pertemuan 2 siswa yang tuntas belajar sebanyak 1 siswa. Jadi secara keseluruhan pelaksanaan siklus I pembelajaran Tematik menggunakan Metode Index Card Match pada materi Hari Akhir menunjukkan adanya peningkatan pemahaman konsep, keaktifan dan ketuntasan klasikal meskipun belum memenuhi standar KKM yang ditentukan oleh peneliti. Melihat dari hasil evaluasi siklus I menghasilkan beberapa catatan yang harus direfleksikan pada pelaksanaan pembelajaran siklus II yaitu sebagai berikut:

1. Guru kurang menguasai skenario pembelajaran, sehingga perjalanan pembelajaran PAI dengan menerapkan Metode Index Card Match kurang lancar/optimal.

2. Guru kurang memberikan bimbingan pada tiap-tiap siswa saat menyelesaikan masalah.

3. Siswa belum diberitahu sebelumnya untuk mempelajari materi Hari Akhir.

4. Siswa cenderung masih pasif.

5. Kendala listrik terkadang pemadaman bergilir.

Berdasarkan evaluasi dari siklus I, refleksi yang dilakukan pada siklus II ini adalah melakukan revisi RPP, lembar kerja dan juga perbaikan saat proses pembelajaran. Pelaksanaan pembelajaran siklus II pada tanggal 22 Agustus dan 1 Maret 2020. Berikut hasil pembelajaran siklus II yang dilihat dari pemahaman konsep dan ketuntasan klasikal:

\section{1) Pemahaman Konsep}

Indikator pembelajaran yang akan dicapai pada siklus II tentunya berbeda dengan siklus I. Kalau pada siklus I siswa diharapkan dapat menunjukkan Hari Akhir, serta mencocokkannya, sedangkan pada siklus II siswa diharapkan dapat menunjukkan serta menyampaikan kembali konsep materi tersebut. Hal ini dapat dilihat dari anak saat menyelesaikan susuna potongan kertas serta menyampaikan kembaliHari Akhir dengan baik.

Berdasarkan nilai rata-rata pada tabel di atas dapat disimpulkan bahwa pembelajaran pada siklus II siswa dapat menguasai konsep dengan baik. Nilai rata-rata kelas yaitu sebesar 82,50 yang menunjukkan sudah jauh di atas indikator yang ditentukan yaitu 70 (KKM). Nilai rata-rata kelas pada siklus II jika dibandingkan siklus I dan pra siklus juga sudah mengalami kenaikan yang signifikan.

\section{Grafik Kenaikan Nilai Rata-Rata Hasil Belajar Setiap Siklus}

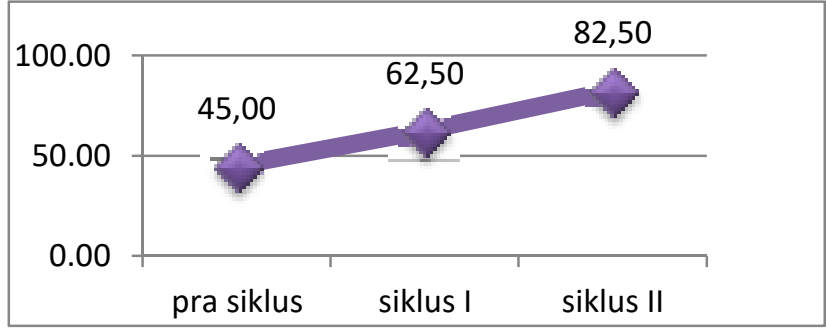




\section{2) Ketuntasan Klasikal}

Berdasarkan persentase ketuntasan belajar pada siklus II di atas menunjukkan hasil 100\%. Jika diukur dengan indikator ketuntasan klasikal yang ditentukan yaitu $75 \%$, pada siklus II ini menunjukkan bahwa semua siswa dianggap tuntas dan memiliki nilai maksimal. Pada siklus II ini semua siswa sudah tuntas dan mendapatkan nilai 100.

Berdasarkan hasil keseluruhan dari pra siklus, siklus I dan siklus II, pelaksanaan pembelajaran pada materi Hari Akhir yang menerapkan Metode Index Card Match menunjukkan adanya peningkatan pemahaman konsep, keaktifan siswa dan ketuntasan klasikal, sehingga pada siklus II semua indikator yang ditentukan sudah dipenuhi, bahkan sampai memenuhi nilai maksimal. 


\section{Kesimpulan}

Berdasarkan data-data yang diperoleh dari serangkaian kegiatan penelitian, diperoleh kesimpulan yaitu metode Index Card Match membuat siswa lebih bersemangat dan bermakna dalam pembelajaran Pendidikan Agama Islam (PAI). Selama proses penelitian berlangsung, terjadi perubahan tingkah laku siswa ke arah positif. Hal ini dibuktikan dengan skor rata-rata aspek pengamatan yang selalu meningkat pada setiap pertemuan.Peningkatan pemahaman konsep terjadi sangat signifikan setiap siklusnya, hal tersebut dilihat dari kenaikan rata-rata nilai pretest yang semula 45,00 kemudian mengalami kenaikan pada siklus I dengan rata-rata 62,50 dan memperlihatkan kenaikan kembali pada siklus II dengan rata-rata sebanyak 82,50. Hal itu juga dapat dilihat dengan nilai ketuntasan klasikal pada setiap siklus yang bermula dari angka 25\% menjadi $100 \%$ siswa dinyatakan tuntas belajar dalam materi Hari Akhir.

\section{DAFTAR PUSTAKA}

Daradjat, Zakiah, dkk, Ilmu Pendidikan Islam, Jakarta: Bumi Aksara, 1996. , Metodologi Pengajaran Agama Islam, Jakarta: PT. Bumi Aksara, 1996.

Morgan, Cillford T., Introduction to Psychology, fourth edition, New York: Mc Grow Hill inc., 1971.

Peraturan Menteri Pendidikan Nasional Republik Indonesia Nomor 22 Tahun 2006, Standar Isi untuk Satuan Pendidikan Dasar dan Menengah, Standar Kompetensi dan Kompetensi Dasar Tingkat SD, MI dan SDLB, Jakarta: CV. Mini Jaya Abadi, 2006.

Silberman, Melvin L., Active Learning 101 Strategi Pembelajaran Aktif, terj. Raisul Muttaqien, (Yogyakarta: Pustaka Insan Madani, 2009).

Soemanto, Wasty, Psikologi Pendidikan, Jakarta: Rineka Cipta, 1990.

Sudjana,Nana dan Ahmad Rivai, Teknologi Pengajaran, Bandung: Sianar Baru Algesindo, 2007. 